\title{
Lack of seasonality in phytoplankton standing stock (chlorophyll a) and production in the western Bay of Bengal
}

\author{
N. V. Madhu*a , R. Jyothibabu ${ }^{a}$, P. A. Maheswaran ${ }^{b}$, Vijay John Gerson ${ }^{a}$, \\ T. C. Gopalakrishnan ${ }^{a}$ \& K. K. C. Nair ${ }^{a}$

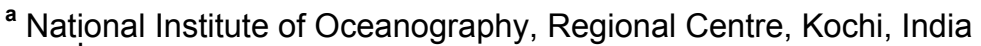

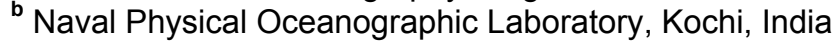

\begin{abstract}
The investigations in the western Bay of Bengal $(\mathrm{BoB})$ during summer, winter and spring intermonsoon periods evidenced lack of pronounced seasonal variation in phytoplankton standing stock (chlorophyll a) and primary production. The supply of riverine materials to the coastal bay is witnessed by the presence of major nutrients (nitrate $-\mathrm{NO}_{3}$, phosphate $-\mathrm{PO}_{4} \&$ silicate $-\mathrm{SiO}_{4}$ ) in the upper layers (up to 20meters) during monsoonal periods. However, it was not found to enhance the phytoplankton production rates to a large extent. The strong stratification due to enormous quantity of fresh water discharge, acts as a barrier to vertical transport of nutrients from the subsurface layers. The average primary production in the inshore and the offshore waters of the BoB were $350 \pm 225$ and $251 \pm 177 \mathrm{mgCm}^{-2} \mathrm{~d}^{-1}$ in summer, 252 \pm 210 and $231 \pm 150 \mathrm{mgCm}^{-2} \mathrm{~d}^{-1}$ in winter and $308 \pm 120$ and $303 \pm 95 \mathrm{mgCm}^{-2} \mathrm{~d}^{-1}$ in spring intermonsoon periods, respectively. Subsurface chlorophyll maxima (SCM) were observed at $20-50 \mathrm{~m}$ in the spring intermonsoon, whereas in summer and winter, the chlorophyll maxima occurred in the upper layers of the euphotic zone $(<20 \mathrm{~m})$. The vertical distribution of phytoplankton $(>5 \mu \mathrm{m})$ was primarily restricted by the pycnocline, and the bulk of phytoplankton assemblage existed within the surface. The seasonal change in cell numbers, however, did not coincide closely with the changes in the chlorophyll a concentration. Diatoms formed the major group (>85\%) in the total phytoplankton abundance irrespective of seasons. During spring intermonsoon, large patches of Trichodesmium blooms were observed in the coastal as well as open waters of the western BoB.
\end{abstract}

Key words: - Bay of Bengal; Chlorophyll a; Primary production; Trichodesmium; Upwelling; Thermal inversion

*Address for correspondence E - mail: - madhunv12@yahoo.com 


\section{Introduction}

The Bay of Bengal (BoB) located between $0^{\circ}$ and $23^{\circ} \mathrm{N}$ and $80^{\circ}$ and $100^{\circ} \mathrm{E}$ and occupying an area of $4.087 \times 10^{6} \mathrm{~km}^{2}$ is a region of positive water balance. It hosts a unique system of inter-related oceanographic and sedimentary processes induced by the seasonally reversing monsoon winds and the enormous supply of fresh water $\left(1.5 \times 10^{12} \mathrm{~m}^{3}\right)$ and silt $\left(16 \times 10^{8} \mathrm{t} / \mathrm{y}\right)$ from several peninsular Indian rivers (Shetye et al., 1996). The freshwater influx induces estuarine characteristics over large areas of the bay, which impedes exchange between the surface and deep waters with consequent impact on biological processes. Rainfall over BoB shows wide spatial variability and strong seasonality: the southeast coast of India has a winter rainfall maximum, whereas the rest of the BoB has a summer monsoon maximum (Ramage, 1984). During summer, large fresh water discharge from the north Indian rivers substantially lowers the salinity and also reduces the intensity of upwelling $\sim 40 \mathrm{~km}$ from the coast (Shetye et al., 1991). This enormous fresh water input causes strong vertical stratification (barrier layer) inhibiting the upliftment of nutrients (Sprintall and Tomczak, 1992; Vinayachandran et al., 2002, Maheswaran, 2004). For example, even though the SST in the northern bay is low $\left(25^{\circ} \mathrm{C}\right)$ during winter, convective overturning is prevented by the stability induced by low saline (<30) surface waters (Jyothibabu et al., 2004; Maheswaran, 2004).

Conventionally BoB is believed to be relatively less productive compared for example with the neighboring Arabian Sea - AS (Qasim, 1977; Radhakrishna et al., 1978; Prasannakumar et al., 2002; Madhu, 2004). The seasonal (upwelling and cold core eddy) and some sporadic events (cyclones) enhance moderate phytoplankton production of the BoB in some areas (Gomes et al., 2000; Madhu et 
al., 2002; Prasannakumar et al., 2004). During spring intermonsoon, eddies and recirculation zones form in the coastal region of the bay due to the western Bay of Bengal current (WBC) found to enhance phytoplankton growth to some extent (Gomes et al., 2000; Prasannakumar et al., 2004). Where as in monsoon seasons (summer \& winter), the nutrient inputs from river runoff, trigger primary production of the coastal waters of the BoB (Gomes et al., 2000; Madhu et al., 2002; Madhupratap et al., 2003). Based on a new and systematic data set, the present study investigates the seasonal change in phytoplankton biomass and primary production in the western BoB with respect to the prevailing physico-chemical environment.

\section{Materials and Methods}

The data were collected from the western BoB (Fig. 1) during spring intermonsoon (April 2000), winter monsoon (December 2000) and summer (July/August 2002) seasons as a part of the project "Marine Research - Living Resources (MR-LR) Assessment" programme funded by Department of Ocean Development (DOD), Govt of India. Winds were monitored by the automated weather station on board the ship. Temperature and salinity were determined from Sea-Bird Electronics CTD (USA, model: SBE-911 plus) data and the sea surface temperature (SST) was measured using bucket-thermometer. The mixed layer

depth (MLD) was determined from density profiles as the depth at which the density difference from the surface was $0.2 \mathrm{kgm}^{-3}$. Similarly, the barrier layer was considered as the layer between the base of the mixed layer and the top of the thermocline (Sprintall and Tomczak, 1992). The water samples for nutrients were collected up to 150 meters (ie, 0, 10, 20, 50, 75,100 \& 150meters) using 5-litre Niskin samplers and 
analyzed with a SKALAR auto-analyser (Model SA - 1050). For the estimation of chlorophyll a and primary production, water samples were collected from discrete depths such as $0,10,20,50,75,100 \& 120$ meters. One-litre seawater samples from each depth were filtered through Whatman GF/F filters (nominal pore size 0.7 $\mu \mathrm{m})$ to determine chlorophyll a using a Perkin-Elmer UV/Vis spectrophotometer (Strickland and Parsons, 1972). Primary production was estimated by in-situ method using the ${ }^{14} \mathrm{C}$ - technique (UNESCO 1994). Seawater samples were collected before sunrise from seven depths mentioned above. Water samples were immediately passed through $200 \mu \mathrm{m}$ plankton net to remove large sized zooplankton and transferred to $300 \mathrm{ml}$ capacity Nalgene bottles. After the inoculation of $\mathrm{NaH}^{14} \mathrm{CO}_{3}$ (activity $5 \mu \mathrm{C}$ ), the light and dark bottles were deployed in-situ in a mooring system for 12 hours. The experiments were terminated by filtering the samples on to $47 \mathrm{~mm}$ Whatman GF/F filters and the filters were used for subsequent analysis in liquid scintillation counter after treatment with $\mathrm{HCl}$ fumes to remove inorganic carbon. The primary productivity rate was calculated according to the equation described in the protocol. The chlorophyll a specific primary production was determined by taking the production value and dividing it by the respective chlorophyll a concentration, generating units of $\mathrm{mgC} \mathrm{mgChl} \mathrm{a}^{-1} \mathrm{hr}^{-1}$

For qualitative studies of phytoplankton $(>5 \mu \mathrm{m}), 500 \mathrm{ml}$ of seawater samples drawn from the depths mentioned above were fixed in $1 \%$ Lugol's iodine and preserved in $3 \%$ formaldehyde solution. The samples were stored in the dark at low temperature until enumeration within a period of one month after collection. A settling and siphoning procedure was followed to obtain $20-25 \mathrm{ml}$ concentrates. One $\mathrm{ml}$ of this concentrated sample was examined microscopically in triplicate under a 
stereoscope binocular microscope (magnification 100x) in a Sedgewick-Rafter counting chamber. Chain-forming cells were counted on a per cell basis and empty cells were excluded. As far as possible, the phytoplankton groups were identified to species, but in some taxonomic groups, identification is confined to genera. Taxonomic criteria and diagnosis for phytoplankton identification mainly relied on Subrahmanyan (1959) and Tomas (1997).

\section{Results}

Hydrography and chemistry

During summer monsoon, the winds were predominantly south-westerlies and occasional north-westerlies with the magnitude often exceeding $6 \mathrm{~ms}^{-1}$ (Figs. 2a, 3a \& 3b). SST did not show much variation between inshore (av. $29.5^{\circ} \mathrm{C}$ ) and offshore (av.29.4 ${ }^{\circ} \mathrm{C}$ ) waters (Figs. 3c \& 3d). A northward decrease in SSS and sigma - $t$ was observed in inshore, as well as offshore waters (Figs. $3 e, 3 f, 3 g \& 3 h$ ). MLD was relatively deep $(>40 \mathrm{~m})$ in the southern region and shallow in the north, where as the barrier layer thickness was less $(<20 \mathrm{~m})$ in the south as compared to north (Figs. 3i \& 3j, 3k \& 3l). The vertical distribution of temperature shows upsloping of isotherms above $50 \mathrm{~m}$, which indicates the signatures of upwelling at $15^{\circ} \mathrm{N}$ inshore waters (Fig. 4a). Similarly, the vertical structure of salinity and sigma - $t$ were evidenced a sharp south-north gradients in the upper $50 \mathrm{~m}$ due to the fresh water influx from the north (Figs. 4c, 4d, 4e \& 4f). Low concentration $(<200 \mu M)$ of dissolved oxygen (DO) was observed in the upper layers of the entire study area during summer (Figs. 5a \& 5b). Inshore region was characterized by shallow nitracline $(\sim 20-30 \mathrm{~m})$, but it was slightly deeper $(\sim 50 \mathrm{~m})$ offshore (Figs. 5c \& 5d). 
Similarly, traces of inorganic phosphate $(\sim 0.4 \mu \mathrm{M})$ and silicate $(\sim 1 \mu \mathrm{M})$ could also noticed in the upper $50 \mathrm{~m}$ of northern inshore waters, while it was lacking in offshore (Figs. $5 e, 5 f, 5 g$ \& $5 \mathrm{~h}$ ). Besides that, the upward shift of isolines of nitrate and phosphate in the $15^{\circ} \mathrm{N}$ inshore waters, strongly support the signatures of upwelling.

Generally, weak winds (av. $3.7 \mathrm{~ms}^{-1}$ ) were prevalent in the study area during winter monsoon (Figs. 2b, 3a \& 3b). Inshore SST showed a warming trend towards north upto $15^{\circ} \mathrm{N}$, thereafter it decreased and showed a minimum $\left(\sim 26.0^{\circ} \mathrm{C}\right)$ at $20.5^{\circ} \mathrm{N}$ (Figs. 3c \& 3d). Where as in the offshore, SST showed a steady decrease towards north (a gradient of $2.2^{\circ} \mathrm{C}$ from $11^{\circ} \mathrm{N}$ to $20.5^{\circ} \mathrm{N}$ ). Similarly, SSS also showed a steady decrease of $\sim 4$ from $11^{\circ} \mathrm{N}$ to $20.5^{\circ} \mathrm{N}$ in the offshore region but inshore SSS showed a fluctuating trend from north to south (Figs. 3e \& 3f). Prominent south-tonorth decrease in surface sigma- $t$ was observed both inshore as well as offshore waters (Figs. $3 g$ \& 3h). Generally, MLD was shallow all over the area (inshore av. $20 \mathrm{~m} \&$ offshore av. $33 \mathrm{~m}$ ) during this season, while the barrier layer was relatively thicker $(>40 m)$ in the inshore-offshore waters of northern region (Figs. 3i, 3j, 3k \& 3l). Distinct thermal inversion was observed in the north with relatively cold surface waters $\left(<28^{\circ} \mathrm{C}\right)$ overlying the warm $\left(>28^{\circ} \mathrm{C}\right)$ subsurface layers (Figs. $\left.4 \mathrm{~g} \& 4 \mathrm{~h}\right)$. Vertical structure shows inshore waters characterized by low salinity $(<30)$ with low density $(<20)$, which found to spread over $30 \mathrm{~m}$ in the entire coast (Figs. 4i \& 4k). But in offshore, the low salinity waters were restricted in the north (Figs. 4j \& 4I). DO was saturated in the surface layers of both inshore $(>200 \mu \mathrm{M})$ and offshore waters (Figs. 5i \& 5j). Traces of inorganic nutrients (nitrate, phosphate and silicate) were observed above 50m inshore waters as compared to offshore (Figs. 5). 
During spring intermonsoon, strong winds $\left(\sim 12 \mathrm{~ms}^{-1}\right)$ were observed in the northern inshore (especially $19^{\circ} \& 20.5^{\circ} \mathrm{N}$ ) region of the BoB (Figs. 2c, 3a \& 3b). SST showed relatively high values in the entire area $\left(>29^{\circ} \mathrm{C}\right)$ and the inshoreoffshore variability in SST was minimum (Figs. 3c \& 3d). SSS and surface sigma-t were also found to be high $(>32 \&>20)$ during this season compared with the other two seasons (Figs. 3g, 3h, 3i \& 3j). Shallow MLD $(2-30 m)$ and thin barrier layer $(<15 \mathrm{~m})$ was observed all over the area during this season (Figs. 3i, 3j, 3k \& 3l). Vertical distribution of temperature in the upper layers showed an upsloping towards north and also strong thermal stratification (Figs. $4 m \& 4 n$ ). The vertical salinity structure in the upper layers shows relatively high salinity (33 - 35.5) with minimum gradients due to the reduction in fresh water (Figs. $40 \& 4 p$ ). The vertical density structure shows more similarity to temperature structure (Figs. $4 q$ \& $4 r$ ). High concentration of DO $(>200 \mu \mathrm{M})$ evidenced in the upper layers of both inshore and offshore waters (Figs. $5 q \& 5 r)$ A relatively deeper nutracline $(\sim 50 \mathrm{~m})$ was also a characteristic feature in the upper layers during this season (Figs. $5 s \& 5 t, 5 u, 5 v, 5 w$ $\& 5 x)$.

\section{Chlorophyll a}

During summer, inshore waters exhibited somewhat higher chlorophyll a concentration (surface av. $0.43 \pm 0.6 \mathrm{mgm}^{-3}$; column av. $21.9 \pm 16.8 \mathrm{mgm}^{-2}$ ) in the BoB than the corresponding offshore waters (surface $-0.19 \pm 0.08 \mathrm{mgm}^{-3}$, column $\left.14.1 \pm 6.3 \mathrm{mgm}^{-2}\right)$. Southern inshore waters showed low chlorophyll a $\left(<0.1 \mathrm{mgm}^{-3}\right)$ as compared to the northern inshore. Moreover, an anomalous increase in chlorophyll a (surface $-1.4 \mathrm{mgm}^{-3}$; column $-42.8 \mathrm{mgm}^{-2}$ ) was observed at $15^{\circ} \mathrm{N}$ 
coastal waters, which supports the biological signatures of upwelling. The chlorophyll maxima was mostly confined to $<20 \mathrm{~m}$ at most of the stations, which indicated the absence of subsurface chlorophyll maxima (SCM). The average chlorophyll a (both surface and column) showed slightly higher values in the inshore waters than the corresponding offshore (Figs $6 a \& 6 b$ ). During winter monsoon season, the chlorophyll a showed a more or less similar trend as observed in summer (inshore av. $0.17 \pm 0.14 \mathrm{mg} \mathrm{m}^{-3}$; offshore av. $0.14 \pm 0.07 \mathrm{mgm}^{-3}$ ) although, the integrated column chlorophyll a was rather less (inshore av. $13.0 \pm 7.7 \mathrm{mgm}^{-2}$, offshore av. $11.5 \pm 4.1 \mathrm{mgm}^{-2}$ ). Like the summer monsoon, the chlorophyll maxima also found to remain in the surface layers $(0-20 m)$ during winter (Fig 7). Spring intermonsoon showed relatively less concentration of surface chlorophyll a (av. $<0.3 \mathrm{mgm}^{-3}$ ) in the entire region, while the integrated column chlorophyll a was comparable with summer and winter monsoon seasons (Figs. 6a \& 6b). The SCM was slightly deeper $(\sim 50 \mathrm{~m})$ during spring intermonsoon in contrast to summer and winter monsoon (Fig 7).

\section{Primary production}

During the summer monsoon, similar to chlorophyll a distribution, the BoB had lower production rates in the southwest region than the northwest, except the inshore waters off $15^{\circ} \mathrm{N}$. The average surface primary production showed a two-fold increase between the inshore (av. $16.1 \pm 18.4 \mathrm{mgC} \mathrm{m}^{-3} \mathrm{~d}^{-1}$ ) and offshore waters (av. $7.5 \pm 7.1 \mathrm{mgC} \mathrm{m}^{-3} \mathrm{~d}^{-1} ;$ Fig $6 \mathrm{c}$ ). Where as the integrated column primary production did not show much variability (inshore $-350 \pm 225 \mathrm{mgC} \mathrm{m}^{-2} \mathrm{~d}^{-1} \&$ offshore $-251 \pm 177$ $\left.\mathrm{mgC} \mathrm{m}^{-2} \mathrm{~d}^{-1}\right)$. Maximum surface primary production was recorded off $15^{\circ} \mathrm{N}$ inshore 
$\left(45.8 \mathrm{mgC} \mathrm{m}^{-3} \mathrm{~d}^{-1}\right)$, but the maximum column primary production $\left(621 \mathrm{mgC} \mathrm{m}^{-2} \mathrm{~d}^{-1}\right)$ was observed at inshore waters off $20.5^{\circ} \mathrm{N}$. During the winter monsoon, the average surface primary production showed a similar trend to that observed in summer; but the rate of production appeared less (inshore av. $8.6 \pm 10.6 \mathrm{mgC} \mathrm{m}^{-3} \mathrm{~d}^{-}$ ${ }^{1}$; offshore av. $4.0 \pm 2.6 \mathrm{mgC} \mathrm{m}^{-3} \mathrm{~d}^{-1}$; Figs. $6 \mathrm{c} \& 6 \mathrm{~d}$ ). On the other hand, the average water column primary production was more or less similar in inshore (av. $252 \pm 210$ $\mathrm{mgC} \mathrm{m} \mathrm{d}^{-1}$ ) and offshore (av. $231 \pm 150 \mathrm{mgC} \mathrm{m}^{-2} \mathrm{~d}^{-1}$ ). Like chlorophyll a, the average primary production rates during spring intermonsoon was relatively less (av. $\left.<6 \mathrm{mgCm}^{-3} \mathrm{~d}^{-1}\right)$ in the surface compared to other two seasons, while the average integrated column primary production appears to slightly high (av. $305 \mathrm{mgC} \mathrm{m}^{-2} \mathrm{~d}^{-1}$ ) compared to summer and winter monsoon seasons (Figs. 6c \& 6d).

\section{Chlorophyll a specific primary production}

The values of chlorophyll a - specific primary production, an index of phytoplankton growth rate (Lalli and Parsons, 1993) also did not show marked seasonal variations. The average values of chlorophyll a - specific primary production in the inshore surface waters were $3.1 \pm 1.5,2.1 \pm 0.3$ and $2 \pm 1 \mathrm{mgC}$ $\mathrm{mgChl} \mathrm{a}^{-1} \mathrm{hr}^{-1}$ respectively, during summer, winter and spring intermonsoon periods. While in the offshore, the corresponding values were $2.8 \pm 2.8,3.4 \pm 5.2$ and $2.5 \pm$ $1.6 \mathrm{mgC} \mathrm{mgChl} \mathrm{a}^{-1} \mathrm{hr}^{-1}$, respectively.

\section{Phytoplankton abundance and composition}

Eighty-six species of phytoplankton (diatoms - 68 species and dinoflagellates

- 17) from various depths were encountered during summer (Table 1). The 
abundance in the surface was relatively higher inshore (av. 15227cells I $^{-1}$ ) compared to offshore (av. 4039 cells I $^{-1}$ ). The abundance in the vertical water column was also more inshore (av. $151.63 \times 10^{6}$ cells $\mathrm{m}^{-2}$ ) than the offshore (av. $121.34 \times 10^{6}$ cells m$\left.{ }^{2}\right)$. Generally, diatoms formed the major component (88 - 99\%) of the total phytoplankton density followed by dinoflagellates (1 - 10\%). Among diatoms, the pennate group showed the dominance (av. $71 \times 10^{6}$ cells $\mathrm{m}^{-2}$ ) over the centric group (av. $42.9 \times 10^{6}$ cells $\mathrm{m}^{-2}$ ). The genus Thalassionema formed the most abundant group (Thalassionema frauenfeldii ca. 42\% \& Thalassionema nitzschioids ca. 23\%) in the upwelled waters $\left(15^{\circ} \mathrm{N}\right)$. Other dominant groups encountered during this period were, Rhizosolenia delicatula, Nitzschia seriata, Nitzschia closterium, Navicula directum, Coscinidiscus sp., Biddulphia sinensis, Ditylum brightwelli, Skeletonema costatum etc and the dinoflagellates were Ceratium furca, Prorocentrum sp., Oxytoxum scolopex, Peridinium sp., Dinophysis sp., etc.

During the winter monsoon, similar to the summer monsoon, the diatoms constituted 91 to $95.4 \%$ in the total phytoplankton population, followed by dinoflagellates $(0.9-7.2 \%)$. Pennate diatoms (av. $85.9 \times 10^{6}$ cells $\mathrm{m}^{-2}$ ) dominated over centrals (av. $71 \times 10^{6}$ cells $\mathrm{m}^{-2}$ ) in total diatom density. The dominant diatom species encountered during this season were Thalassionema nitzschioids, Skeletonema costatum, Coscinodiscus sp., Thalassiothrix longissima, Nitzschia seriata, Chaetoceros sp., Rhizosolenia sp., etc and the dinoflagellates were Prorocentrum sp., Ceratium macroceros, Ceratium bucephalum, Ceratium furca, Ornithocercus sp., Gymnodinium sp., Gonyaulax sp. (Table 2).

Extensive thick patches of Trichodesmium erythraeum blooms (Plates 1a, 1b \& 1c), characteristic feature of oligotrophic tropical and subtropical waters were 
encountered in the open waters (off Karaikkal - 1058' N; $81^{\circ} 50^{\prime} \mathrm{E}$ and off south of Calcutta $-19^{\circ} 44^{\prime} \mathrm{N}, 89^{\circ} 04^{\prime} \mathrm{E}$ ) and also some coastal region (thin patches only) of the BoB during the spring intermonsoon. Eventhough, in general the total phytoplankton abundance was relatively low in the $\mathrm{BoB}$, the bloom area shows high numerical abundance due to proliferation of Trichodesmium erythraeum. The numbers of phytoplankton taxa were also less during this period, (diatoms - 42, dinoflagellates 10 , others - 3) compared to other seasons. On an average, the diatoms constituted $<88 \%$ in the study area, followed by dinoflagellates $(7.5 \%)$. The diatoms, Nitzschia seriata and Skeletonema costatum were most common in inshore, where as in the open ocean waters Chaetoceros sp., Rhizosolenia sp.and of some other times Trichodesmium erythraeum were also found to dominate during this period. Other species were Thalassionema nitzschioids, Thalassionema frauenfeldii, Pleurosigma sp., Thalassiothrix longissima, Navicula sp., etc. The major dinoflagellates were Prorocentrum sp., Ceratium bucephalum, Ceratium macroceros, Ornithocercus sp., Peridinium sp. etc.

\section{Discussion}

During summer, the direction of the wind along the coast was favourable for offshore-wind driven Ekman transport that would drive upwelling along the coast (Fig 2). However, the signatures of upwelling such as cold waters, shallow mixed layer, upsloping of isolines of temperature, salinity, density and nitrate towards the coast were evident only at $15^{\circ} \mathrm{N}$ (Figs. 4 \& 5). The enormous fresh water discharge from the north (Ganges - Brahmaputra - Mahanadi river system) leads to the formation of a salinity front at the outer edge of an upwelling front, which is 
responsible for an equatorward flow that found to overwhelm the upwelling in the north during summer (Gopalakrishna and Sastry, 1985; Shetye et al., 1991). Murty and Varadachari (1968) and de Sousa et al., (1981) reported localized mild upwelling along the southern part of the western boundary of BoB in summer. Shetye et al (1991) stated that upwelling along the east coast was normally found to be restricted $\sim 40 \mathrm{~km}$ wide band, and delineate the structure of the upwelling band and its transition from south to north along western BoB. The shallow nitracline $(\sim 20$ to $30 \mathrm{~m}$ ) in inshore waters might be partly due to river discharge and partly upwelling process (Figs. 5c). Besides that, high concentration of nutrients (nitrate $-1 \mu \mathrm{M}$, phosphate $-<0.4 \mu \mathrm{M}$ and silicate $-<2 \mu \mathrm{M})$ found in the upper layers of the northern inshore $\left(20.5^{\circ} \mathrm{N}\right)$ waters substantiates the enormous riverine input during summer.

The increase in primary production (surface $-45.8 \mathrm{mgC} \mathrm{m}^{-3} \mathrm{~d}^{-1}$; column -470 $\mathrm{mgC} \mathrm{m}^{-2} \mathrm{~d}^{-1}$ ), chlorophyll a (surface $-1.4 \mathrm{mgm}^{-3}$; column $-42.8 \mathrm{mgm}^{-2}$ ) and total phytoplankton abundance (surface -52550 cells $\mathrm{I}^{-1}$; column $-439.39 \times 10^{6}$ cells $\mathrm{m}^{-2}$ ) at $15^{\circ} \mathrm{N}$ inshore waters, strongly support the biological evidence for upwelling, even though the upwelling induced primary production was relatively less in the $\mathrm{BoB}$ as compared with the west coast of India (Bhattathiri et al., 1996, Madhu, 2004). Radhakrishna et al, (1978) reported a wide range in chlorophyll a (surface -0.08 to $1.67 \mathrm{mgm}^{-3}$; column -8.6 to $28.5 \mathrm{mgm}^{-2}$ ) in the western BoB during 1976 summer. For 1978 summer, Bhattathiri et al., (1980) also reported similar chlorophyll concentrations (surface -0.01 to $1.01 \mathrm{mgm}^{-3}$, column -1.3 to $33.7 \mathrm{mgm}^{-2}$ ) in the area. Even though some areas in the western BoB showed high concentrations of chlorophyll a (av. $>100 \mathrm{mgm}^{-2}$ ), these values did not lead to high productivity of the area due to cloud cover (Gomes et al., 2000). Similarly, surface productivity 
maxima in BoB can be observed only during the summer monsoon, when the light level was very low $\left(500 \mu \mathrm{Em}^{-2} \mathrm{~s}^{-1}\right)$. The studies of Madhu et al (2002) recorded low phytoplankton biomass and production in the continental shelf (av. $8 \mathrm{mgm}^{-2}$ \& $\left.289 \mathrm{mgC} \mathrm{m}^{-2} \mathrm{~d}^{-1}\right)$ and offshore waters $\left(8.2 \mathrm{mgm}^{-2} \& 240 \mathrm{mgC} \mathrm{m}^{-2} \mathrm{~d}^{-1}\right)$ of southeast coast of India in summer. Recently, as a part of Bay of Bengal Process Studies (BOBPS), Madhupratap et al, (2003) reported relatively high primary production in the open waters (328 to $520 \mathrm{mgC} \mathrm{m}^{-2} \mathrm{~d}^{-1}$ ) compared to the coastal waters (90 to 220 $\mathrm{mgC} \mathrm{m}^{-2} \mathrm{~d}^{-1}$ ) of the BoB.

Apart from the upwelling-induced primary production $\left(15^{\circ} \mathrm{N}\right)$, moderate levels of production were also observed in the northwestern BoB $\left(19 \& 20.5^{\circ} \mathrm{N}\right)$ in summer. The higher phytoplankton biomass $\left(36.6 \mathrm{mg} \mathrm{m}^{-2}\right)$ and production $\left(621 \mathrm{mgC} \mathrm{m}^{-2} \mathrm{~d}^{-1}\right)$ in the north (especially inshore waters off $20.5^{\circ} \mathrm{N}$ ) was also reflected in the total phytoplankton population density $\left(244.92 \times 10^{6}\right.$ cells $\left.\mathrm{m}^{-2}\right)$. Diatoms, the most abundant group $(99.3 \%)$ were dominated $\left(239.46 \times 10^{6}\right.$ cells $\left.\mathrm{m}^{-2}\right)$ in the low saline waters of the north, perhaps because of the riverine supply of silicate $(\sim 2 \mu \mathrm{M})$ in the surface layers as compared to the concentration of nitrate (Fig. 4g). This is substantiated by the reports of De et al., (1991), which showed that the concentration of dissolved silica is high in the north compared with that of dissolved nitrate. In summer, a significant linear correlation $(P<0.01)$ was observed in the phytoplankton biomass with primary production (inshore $-r=0.787$; offshore $-r=$ 0.612 ) and phytoplankton density (inshore $-r=0.557$; offshore $-r=0.063$ ), except for the insignificant relation of chlorophyll a with phytoplankton density in the offshore region (Figs. 8a, 8b, 8c \& 8d). 
Thermal inversion, the prominent feature in BoB during winter was more pronounced $\left(>3^{\circ} \mathrm{C}\right)$ in the north, while in south it was relatively less $\left(\sim 0.5^{\circ} \mathrm{C}\right.$; Fig 9$)$. Many authors have reported the phenomenon of thermal inversion in the BoB (Shetye et al., 1996; Han et al., 2001; Pankajakshan et al., 2002, Maheswaran 2004). Shetye et al. (1996) suggested that the process of inversion in the BoB starts in the north during summer monsoon and accelerates with the onset of the northeast monsoon, when cold continental winds cool the surface waters of the bay particularly in the north. Nevertheless, though SST is low $\left(\right.$ ca. $25.8^{\circ} \mathrm{C}$ ) in the north, winter cooling did not lead to convective mixing and enrichment of upper layers in the BoB due to intense stratification by the fresh water cap (Banse, 1984; Prasannakumar and Prasad, 1996; Madhupratap et al., 1996, Jyothibabu et al., 2004). The presence of nitrate $(1 \mu \mathrm{M})$ in the surface layers $(<20 \mathrm{~m})$ of the northern region might be due to the inputs from rivers rather than to winter convective mechanisms (Fig. $5 k)$.

During winter, the southwestern $\mathrm{BoB}\left(11^{\circ} \mathrm{N} \& 15^{\circ} \mathrm{N}\right)$ shows relatively high phytoplankton standing stock and production, compared to the northwest. The low salinity $(25.9$ - 27.1) in this area was evidenced for the heavy river discharge (Cauvery, Krishna and Godavari) in association with the northeast monsoon rainfall. Similarly, traces of nitrate $(1 \mu \mathrm{M})$ in the top $50 \mathrm{~m}$ inshore waters might have arisen from the riverine input, which ultimately enhances primary production $\left(566 \mathrm{mgC} \mathrm{m}^{-2} \mathrm{~d}^{-}\right.$ 1 \& $\left.433 \mathrm{mgCm}^{-2} \mathrm{~d}^{-1}\right)$ and chlorophyll a $\left(21.5 \mathrm{mg} \mathrm{m}^{-2} \& 22.9 \mathrm{mgm}^{-2}\right)$, and total phytoplankton abundance $\left(144.5 \times 10^{6}\right.$ cells $\mathrm{m}^{-2} \& 229.40 \times 10^{6}$ cells $\left.\mathrm{m}^{-2}\right)$ in $11^{\circ}$ and $15^{\circ} \mathrm{N}$ of southern BoB. Ramage (1971) reported that December - February months bring heavier rainfall to southeastern India than to the northeastern region. Madhu 
et al. (2002) reported enhanced primary production (av. $734 \mathrm{mgC} \mathrm{m}^{-2} \mathrm{~d}^{-1}$ ) in the southeast coast $\left(11^{\circ}-15^{\circ} \mathrm{N}\right)$ of India in association with the super cyclone that hit to Orissa coast on October 1999 and in general, land run off by the heavy rainfall caused the high nutrient concentrations. Significant linear correlation $(P<0.01)$ was observed between chlorophyll $a$ and primary production and phytoplankton abundance during this season (Figs. 8e, $8 f, 8 g \& 8 h$ ).

The warm surface water $\left(>29^{\circ} \mathrm{C}\right)$ and associated thermal stratification was a well-known feature in the BoB during spring intermonsoon. Shetye et al (1993) observed several warm water recirculation zones in the northwestern $\mathrm{BoB}$, in association with the poleward flow of East India Coastal Current (EICC) north of $10^{\circ} \mathrm{N}$, which carry nutrient poor warm water from the south. Similarly, the studies on nutrient distribution in the western BoB showed that during March - April months, rivers flowing in to the $\mathrm{BoB}$ might not contribute much to the inorganic nutrient pool (Sengupta et al., 1977; Rao et al 1994). These are the reasons why the upper layers of the $\mathrm{BoB}$ are devoid of nutrients in the spring intermonsoon. Obviously, this nutrient depleted condition might have lead to the oligotrophic nature of the BoB in spring. Generally on average, the concentration of chlorophyll a and primary production was found to be low in the BoB, but the values seem slightly high (inshore - $15.3 \mathrm{mg} \mathrm{m}^{-2} \& 307 \mathrm{mgC} \mathrm{m}^{-2} \mathrm{~d}^{-1}$ and offshore $-14.1 \mathrm{mg} \mathrm{m}^{-2} \& 303 \mathrm{mgC} \mathrm{m}^{-2} \mathrm{~d}^{-1}$ ) when compared with winter monsoon (Fig. 6). In addition to less nutrient input, increased irradiance and strong thermal stratification also lead to the low phytoplankton production in the western $\mathrm{BoB}$ during spring. The formation of large patches of cyanobacterial blooms (Trichodesmium erythraeum) in the coastal as well as open waters substantiated the oligotrophic nature of the BoB during spring intermonsoon. 
Nevertheless, the surface waters of the bloom area have traces of inorganic nitrate (0.05 to $0.14 \mathrm{M})$, which may be due to extracellular products when the

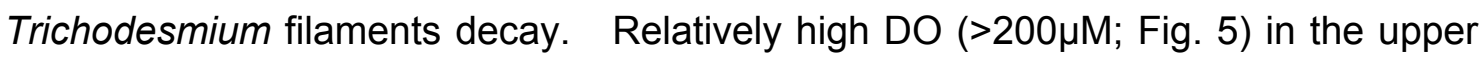
layers of the bay during spring intermonsoon may be due to the lower respiration rate of organic matter and also the lower particle flux (Rao et al., 1994, Unger et al., 2003).

In general, the seasonal (upwelling and cold core eddies) and some sporadic physical events (cyclones) enhance moderate phytoplankton production of the bay in some areas, although these are only transient effects (Gomes et al., 2000; Madhu et al., 2002; Vinayachandran et al, 2003; Prasannakumar et al, 2004). Eventhough the BoB is oligotrophic, nearly $70 \%$ of the phytoplankton standing stock and production exists in the top $50 \mathrm{~m}$ of inshore (av. $71.2 \pm 18.4 \%, \mathrm{n}=17 \& 76.4 \pm 16.2 \%, \mathrm{n}=17$ ) and offshore (av. $63.2 \pm 9.3 \%, n=18 \& 75.9 \pm 10.1 \%, n=18$ ) waters like any other tropical seas (Figs. 10). SCM observed deeper $(\sim 50 \mathrm{~m})$ depths during spring intermonsoon might be due to the high irradiance and thermal stratification. Where as in summer and winter, the chlorophyll maxima restricted to the surface layers $(<20 \mathrm{~m})$ and it could be result of reduced light level by the cloud cover in association with the monsoonal rainfall. Studies of Murty et al (2000) showed that a shallow SCM is prevalent in the coastal waters $(20-30 \mathrm{~m})$ as compared to open waters. Similar to chlorophyll maxima, the primary production maxima were also observed in the surface layers $(<20 \mathrm{~m})$ especially in the summer and winter monsoon periods, which show a direct response to low irradiance. 


\section{Conclusions}

The analyses of our data sets reveals that BoB does not exhibit large-scale seasonal and spatial variability in phytoplankton standing stock and production as its western counter part the AS does. Obviously, the non-accessibility of nutrients due to thermal stratification and low riverine input makes the bay oligotrophic during spring intermonsoon. Where as in summer and winter, the nutrients available in the surface layers (above $50 \mathrm{~m}$ ) of inshore waters (brought by the heavy rain fall and associated riverine input) are not utilized by the phytoplankton, possibly due to the increase in turbidity and intense cloud cover. Riverine influx generates not only the increase in turbidity, but also enhance the formation of barrier layers, which prevent convective mixing in the northern bay, even when the atmospheric cooling is evident. Thus, physical processes in the $\mathrm{BoB}$ are not strong enough to enhance the phytoplankton growth in a great extent as can be observed in the AS. In addition to that in $\mathrm{BoB}$, the studies of photoautotrophic picoplankton, known as the 'prochlorophytes and cyanobacteria', characteristic feature of oligotrophic tropical

and subtropical waters have not been addressed, even though they occupy a key position at the base of the food chain. In future, flow-cytometric studies of prochlorophytes and cyanobacteria will provide much information to the biogeochemical processes and associated carbon fluxes of BoB in detail.

\section{Acknowledgement}

We wish to thank the Director of the National Institute of Oceanography (NIO), Goa for providing facilities for the study. We are grateful to the Centre for Marine Living Resources and Ecology (CMLRE), Department of Ocean Development (DOD) 
for financial support and onboard facilities for carrying out this research. We are extremely thankful to Prof. Trevor Platt, Bedford University, Canada, for his valuable suggestions, which elicited positive thoughts and responses.

\section{References}

1. Banse, K., 1984. Overview of the hydrography and associated biological phenomena in the Arabian Sea off Pakistan. pp. 271-303 in Haq, B. U. and Milliman, J. D. (Eds.), Marine Geology and Oceanography of the Arabian Sea and Coastal Pakistan, Von Nostrand Reinhold, New York.

2. Bhattathiri, P. M. A., V. P. Devassy, and K. Radhakrishna., 1980. Primary production in the Bay of Bengal during southwest monsoon of 1978. Mahasagar - Bull. National Inst. Oceanogr., 13, 315 - 323.

3. Bhattathiri, P. M. A., A. Pant, S. Sawant, M. Gauns, S. G. P. Matondkar, and R. Mohanraju., 1996. Phytoplankton production and chlorophyll distribution in the eastern ad central Arabian Sea in 1994-1995, Curr.Sci., 71, $857-862$.

4. De Sousa, S.N., S. W. A. Naqvi, and C. V. G. Reddy., 1981. Distribution of nutrients in the western Bay of Bengal. Indian J. Mar. Sci., 10, 327-331.

5. De, T. K., S. K. Ghosh, T. K. Jana, A. Choudhury., 1991. Phytoplankton bloom in the Hooghly estuary. Indian J. Mar. Sci., 20, 134-137.

6. Gomes, H. R., J. I. Goes, and T. Saino., 2000. Influence of physical process and freshwater discharge on the seasonality of phytoplankton regime in the Bay of Bengal. Cont. She. Res., 20, 313 - 330. 
7. Gopalakrishna, V. V., and J. S. Sastry., 1985. Surface circulation over the shelf off the east coast of India during southwest monsoon. Indian J. Mar. Sci., 14, 62-65.

8. Han, W., J. P. McCreary, and K. Kohler., 2001. Influence of precipitation minus evaporation and Bay of Bengal rivers on dynamics, thermodynamics, and mixed layer physics in the upper Indian Ocean, J. Geophy. Res., 106, $6895-6916$.

9. Jyothibabu, R., P. A. Maheswaran, N. V. Madhu, T. T. Mohamed Asharaf, V. J. Gerson, P. Venugopal, C. Revichandran, T. Balasubramanian, T. C. Gopalakrishnan, an K. K. C. Nair., 2004. Differential response of winter cooling on biological production in the northeastern Arabian Sea and northwestern Bay of Bengal. Curr. Sci., 87 , 783-791.

10.Lalli, C.M. and T. R. Parsons., 1993. Biological Oceanography: An introduction. Butterworth-Heinemann, Oxford, 301pp.

11. Madhu, N. V., P. A. Maheswaran, R. Jyothibabu, C. Revichandran, T. Balasubramanian, T. C. Gopalakrishnan, and K. K. C. Nair., 2002. Enhanced biological production off Chennai triggered by October 1999 super cyclone (Orissa). Curr. Sci., 82, 1472-1479.

12. Madhu, N. V., 2004. Seasonal studies of primary production and associated environmental parameters in the Indian EEZ. PhD Thesis. Cochin University of Science and Technology, Cochin, India.

13. Madhupratap, M., S. Prasanna Kumar, P. M. A. Bhattathiri, M. Dileepkumar, S. Raghukumar, K. K. C. Nair, and N. Ramaiah., 1996. Mechanism of the 
biological response to winter cooling in the northeastern Arabian Sea. Nature., $384,549-552$.

14. Madhupratap. M., M. Gauns, N. Ramaiah, S. Prasanna Kumar, P. M. Muraleedharan, S. N. de Souza, S. Sardesai, and U. Muraleedharan., 2003. Biogeochemistry of Bay of Bengal: physical, chemical, and primary productivity characteristics of the central and western Bay of Bengal during summer monsoon 2001. Deep - Sea Res. II., 50, 881 - 886.

15. Maheswaran, P. A., 2004. Mixed layer characteristics and hydrography off the west and east coasts of India. PhD Thesis. Cochin University of Science and Technology, Cochin, India.

16. Murty, C. S. and V. V. R. Varadachari., 1968. Upwelling along the east coast of India. Bulletin of National Institute of Sciences., India, 36, 80 - 86.

17. Murty, V. S. N., G. V. M. Gupta, V. V. Sarma, B. P. Rao, D. Jyothi, P. N. M. Shastry, Y. Supravena., 2000. Effect of vertical stability and circulation on the depth of the chlorophyll maximum in the Bay of Bengal during May - June, 1996. Deep - Sea Res. I., 47, 859 - 873.

18. Pankajakshan, T., V. V. Gopalakrishna, P.M. Muraleedharan, G. V. Reddy, N. Araligidad, and S. Shenoi., 2002. Surface layer temperature inversion in the Bay of Bengal. Deep - Sea Res. I., 49, 1801 - 1818.

19.Prasanna Kumar, S. and T. G. Prasad., 1996. Winter cooling in the northern Arabian Sea. Curr. Sci., 71, $834-841$.

20. Prasanna Kumar, S., P. M. Muraleedharan, T. G. Prasad, M. Gauns, N. Ramaiah, S. N. de Souza, S. Sardesai, and M. Madhupratap., 2002. Why is 
the Bay of Bengal less productive during summer monsoon compared to the Arabian Sea? Geophy. Res. Let., 29. 24 2235, doi: 10.1029/2002GL 016013.

21.Prasanna Kumar, S., M. Nuncio, J. Narvekar, Ajoykumar, S. Sardesai, S. N. de Souza, M. Gauns, N. Ramaiah, and M. Madhupratap., 2004. Are eddies nature's trigger to enhance biological productivity in the Bay of Bengal? Geoph. Res. Let., 31, L07309, doi: 10.1029/2003GL 019274.

22. Qasim, S.Z., 1977. Biological productivity of the Indian Ocean. Indian J. Mar. Sci., 6, $122-137$.

23. Radhakrishna, K., P. M. A. Bhattathiri, and V. P. Devassy., 1978. Primary productivity of Bay of Bengal during August - September 1976. Indian J. Mar. Sci., 7, $94-98$.

24. Ramage, C. S., 1971. Monsoon Meteorology. Academic Press, New York, p.296.

25. Ramage, C. S., 1984. Climate of the Indian Ocean north of $13^{\circ} \mathrm{S}$. In world Survey of climatology, 15: Climates of the Oceans, H.Van loon (ed). Amsterdam: Elsevier Scientific, $603-659$.

26. Rao, C. K., S. W. A. Naqvi, M. Dileep Kumar, S. J. D. Varaprasad, D. A. Jayakumar, M. D. George, and S. Y. S. Singbal., 1994. Hydrochemistry of Bay of Bengal: Possible reasons for a different water column cycling of carbon and nitrogen from the Arabian Sea. Mar. Chem., 47, 279 - 290.

27. Sen Gupta, R., S. N. de Souza, and T. Joseph, 1977. On nitrogen and phosphorous in the western Bay of Bengal. Indian J. Mar. Sci., 6, 107 - 110.

28. Shetye, S. R., S. S. C. Shenoi, A. D. Gouveia, G. S. Michael, D. Sundar, and G. Nampoothiri., 1991. Wind driven coastal upwelling along the western 
boundary of the Bay of Bengal during southwest monsoon. Cont. Shelf Res., $11,397-408$.

29. Shetye, S. R., A. D. Gouveia, S. S. C. Shenoi, D. Sundar, G. S. Michael, and G. Nampoothiri., 1993. The western boundary current of the seasonal subtropical gyre in the Bay of Bengal. J. Geophys. Res., 98, 945 - 954.

30. Shetye S. R., A. D. Gouveia, D. Shankar, S. S. C. Shenoi, P. Vinayachandran, D. Sundar, G. S. Michael, and G. Nampoothiri., 1996. Hydrography and circulation in the western Bay of Bengal during northeast monsoon. J. Geophys. Res., 101, 14011-14025.

31.Sprintall. J., and M. Tomczak., 1992. Evidence for barrier layer in the surface layer of the tropics. J. Geophys Res., 97, $7305-7316$.

32. Strickland, J. D. H. and T. R. Parsons, T. R., 1972. In A practical handbook of sea water analysis, $2^{\text {nd }}$ ed. Bull. Fish. Res. Board Can., 167, 310pp.

33. Subrahmanyan, R., 1959. Studies on the phytoplankton of the west coast of India - I and II, Proc. Ind. Acad. Sci., 50 B, 113-252.

34. Tomas. C. R., 1997. Identifying marine phytoplankton. Academic press, USA. 35. UNESCO., 1994. Protocols for the Joint Global Ocean Flux Study, Manual \& Guides, 29, 190.

36. Unger. D., V. Ittekkot., P. Schafer, J. Tiemann, and S. Reschke., 2003. Seasonality and interannual variability of particle fluxes to the deep Bay of Bengal: influence of riverine input and oceanographic processes. Deep-Sea Res. II., 50, 897 - 923. 
37. Vinayachandran, P. N., V. S. N. Murty, and V. Ramesh Babu., 2002. Observations of barrier layer formation in the Bay of Bengal during summer monsoon. J. Geophys. Res. 107, (C 12), 8018, doi: 10.1029/2001GL000831.

38. Vinayachandran, P. N, and S. Mathew., 2003. Phytoplankton bloom in the Bay of Bengal and its intensification by cyclones. Geophys. Res. Lett., 30 (11) 1572;doi:10.1029/2002 GL.016717. 


\begin{tabular}{|c|c|c|}
\hline Bacillariophyceae & C.affinis & N. closterium \\
\hline Centrales & C.curvisetus & N. longissima \\
\hline Melosira $\mathrm{sp}$. & C. pelagicus & N. seriata \\
\hline Skeletonema costatum* & C.danicus & Surirella sp. \\
\hline Thalassiosira subtilis* & C.dedymus & \\
\hline T. hyaline & C.holsaticum & Dinoflagellates (Pyrrophyceae) \\
\hline Stephanopyxis sp. & Eucampia sp. & Prorocentrum sp. \\
\hline Cyclotella $\mathrm{sp}$. & Hamialus huckii & P. rostratum \\
\hline Coscinodiscus sp. & Climacodium sp. & Exuviella sp. \\
\hline C. lineatus & Ditylum brightwelli & Dinophysis sp. \\
\hline C. nitidus & Triceratium sp. & Amphisolenia sp. \\
\hline C.centralis & Biddulphia sinensis & Ornithocercus sp. \\
\hline C.marginalis & B. granulata & Gymnodinium sp. \\
\hline Planktoniella sol & Pennales & Noctiluca miliaris \\
\hline Actinoptychus undulatus & Licmophora sp. & Ceratium sp. \\
\hline Asteromphalus sp. & Synedra sp. & C.bucephalum \\
\hline Aulacodiscus sp. & Thalassionema bacillare & C.furca \\
\hline Corethron sp. & T. nitzschioids* & C.fuscus \\
\hline Lauderia annulata & T. frauenfeldii $*$ & C.lineatum \\
\hline Shroederella sp. & T. longissima & C.tripos \\
\hline Leptocylindrus danicus & Asterionella japonicus & C.macroceros \\
\hline Rhizosolenia $\mathrm{sp}^{*}$. & Gyrosigma sp. & Gonyaulax sp. \\
\hline R.stolterforthii & Pleurosigma sp. & Oxytoxum scolopex \\
\hline R.styliformis & P. elongatum & Pyrocystis sp. \\
\hline R.setigera & $P$. directum & Peridinium sp. \\
\hline R.hebatata & P. normanii & Podolampus sp. \\
\hline R.alata & P. delicatula & \\
\hline R.cylindrus & P. angulatum & Silicoflagellates \\
\hline R.castracanei & Diploneis sp. & Dictyocha sp. \\
\hline Guinardia striata & Navicula sp. & \\
\hline Bacteriastrum delicatula & Navicula directum & Coccolithophores \\
\hline B.hyalinum & Amphiprora sp & Coccolithus sp. \\
\hline B.comosum & Amphora sp. & Rhabdosphaera sp. \\
\hline Cheatoceros sp. & Cymbella sp. & Blue green algae (Cyanophyceae) \\
\hline C.diversus & Nitzschia sp. & Trichodesmium erythraeum* \\
\hline
\end{tabular}

Table. 1 - The list of phytoplankton species identified during different seasons in the western BoB. Designated dominant species in each taxonomic group are those with an asterisk. 

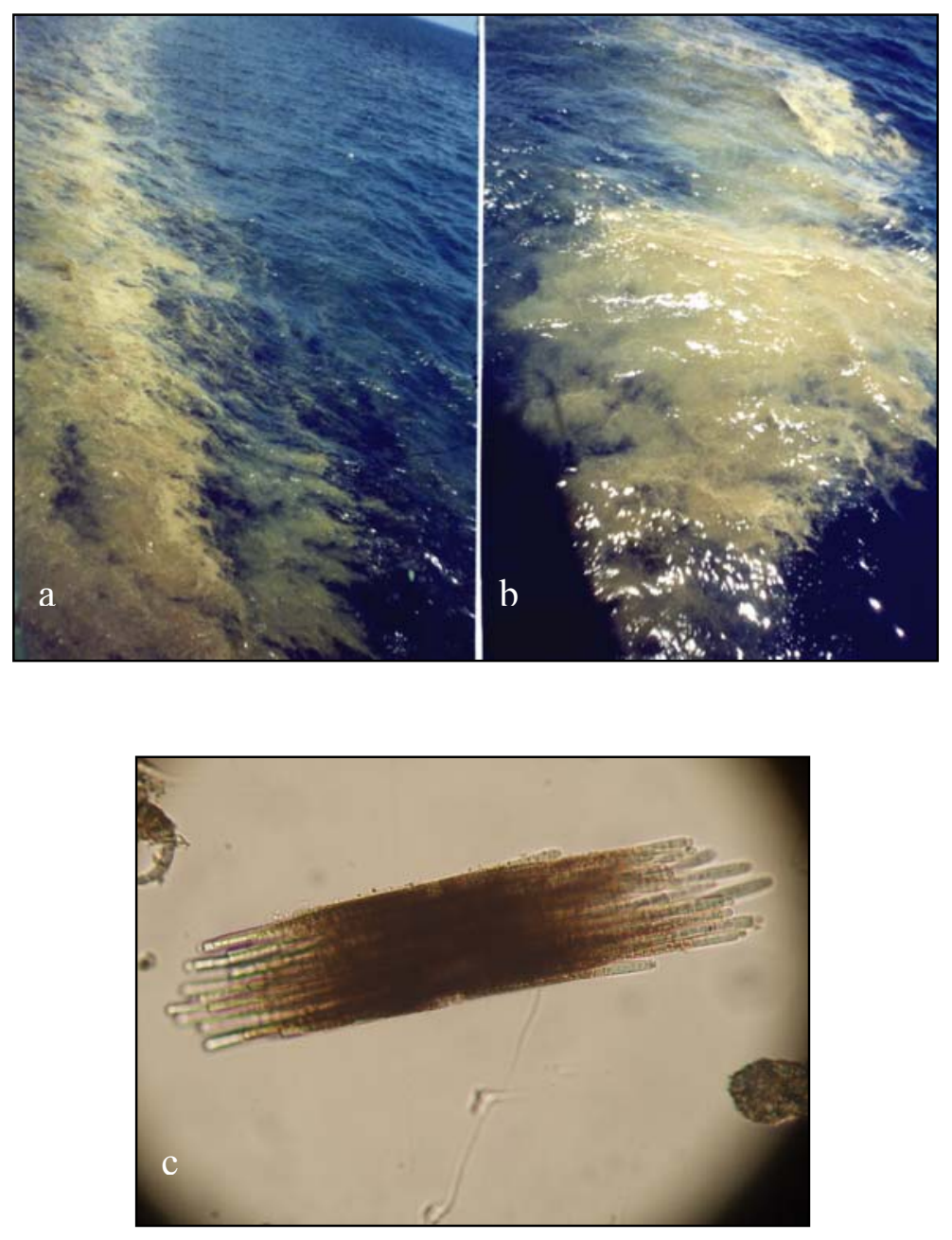

Plate 1 - Patches of Trichodesmium erythraeum bloom observed (a) off Karaikkal (1058' N; $\left.81^{\circ} 50^{\prime} \mathrm{E}\right)$ and (b) off south of Calcutta $\left(19^{\circ} 44^{\prime} \mathrm{N}\right.$; $\left.89^{\circ} 04^{\prime} \mathrm{E}\right)$ during spring intermonsoon period, c) microscopic view (20x) of Trichodesmium erythraeum 


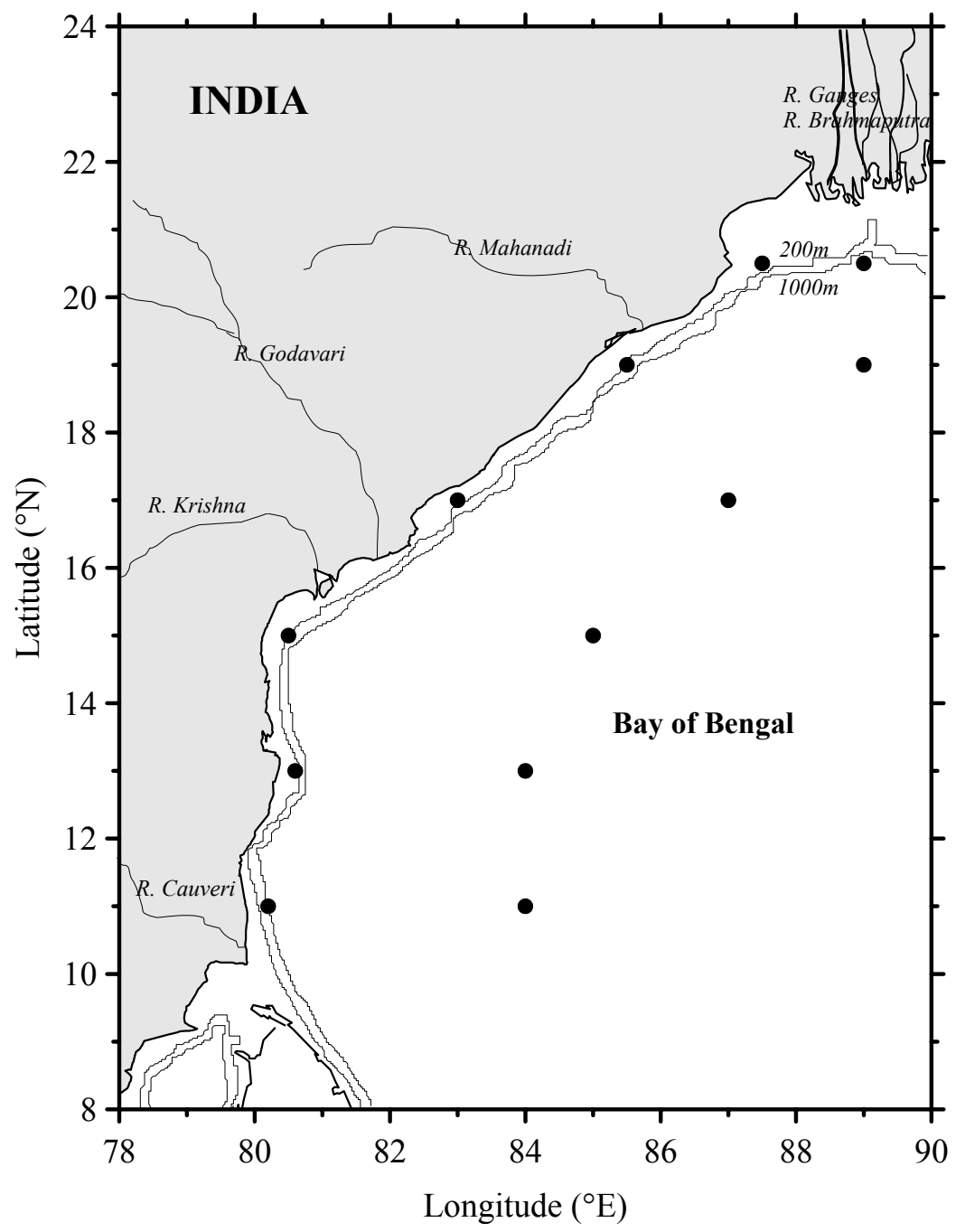

Figure. 1 - Map of the study area with station location 

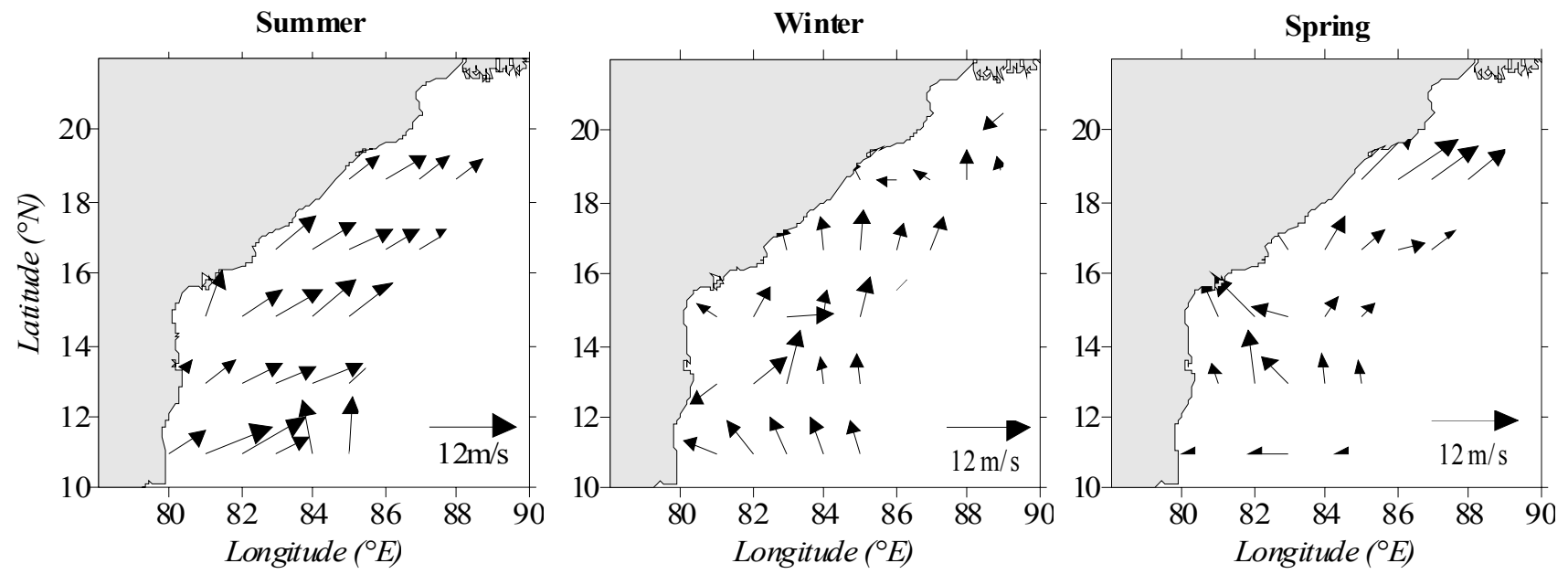

Figure. 2 - Direction and magnitude of wind in the western Bay of Bengal during three different seasons 
Inshore

a
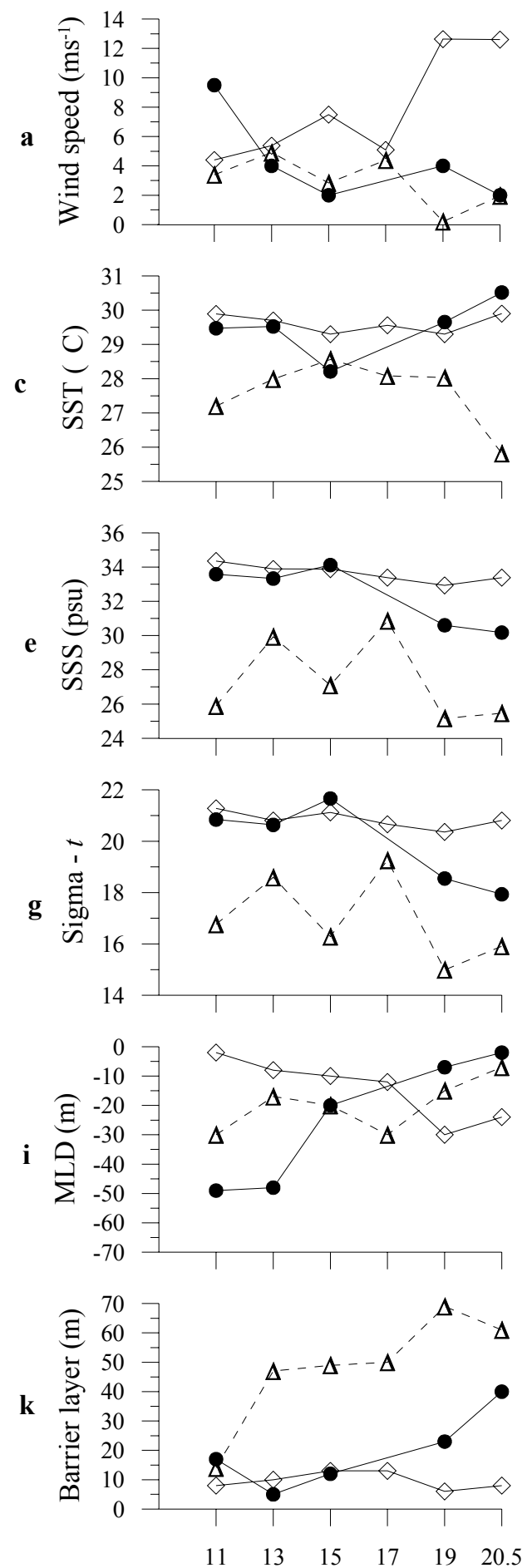

Offshore

b
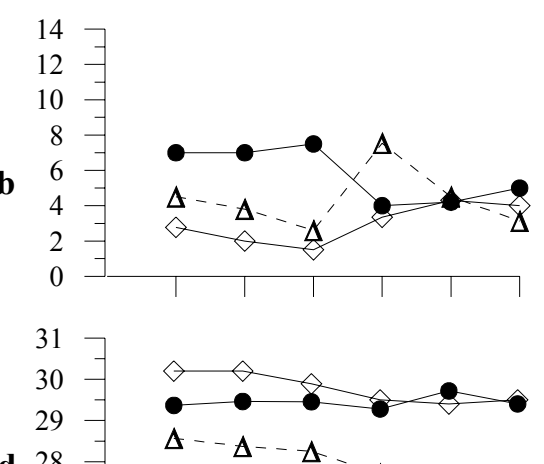

$\Delta$

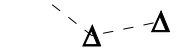

d 28

$\Delta-\Delta-\Delta$

25
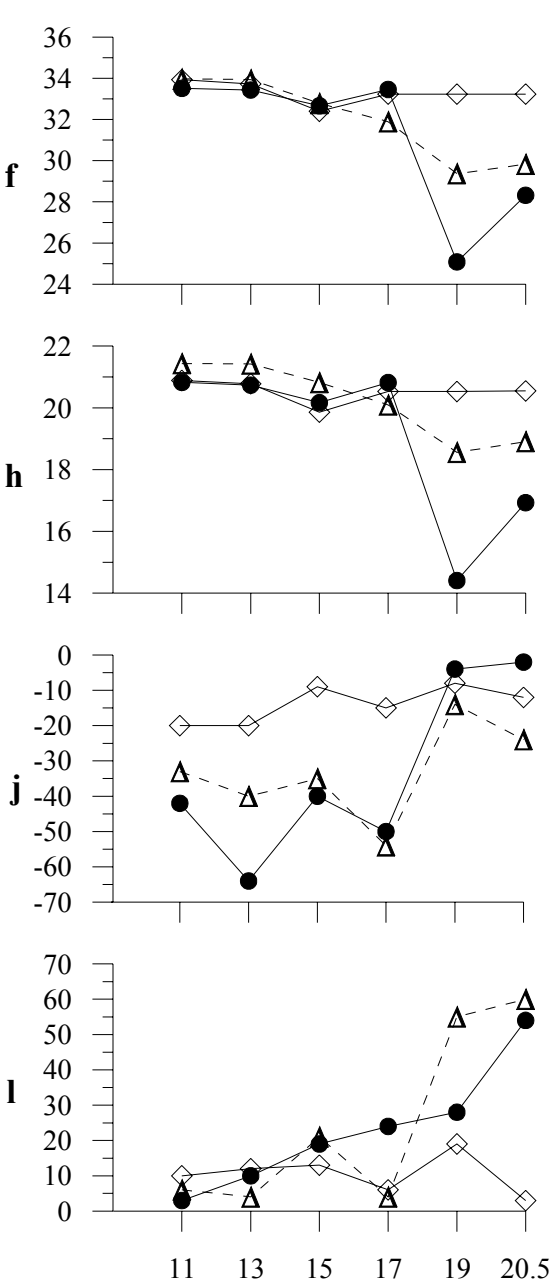

------Latitude $\left({ }^{\circ} \mathrm{N}\right)-------$

\section{- Summer $\Delta$ Winter $\diamond$ Spring inter monsoon}

Figure. 3 - Distribution of wind speed $\left(\mathrm{ms}^{-1}\right)$, SST $\left({ }^{\circ} \mathrm{C}\right)$, SSS, Sigma-t, MLD $(\mathrm{m})$ and barrier layer depth $(\mathrm{m})$ along the inshore and offshore waters of western Bay of Bengal during summer, winter and spring intermonsoon periods 


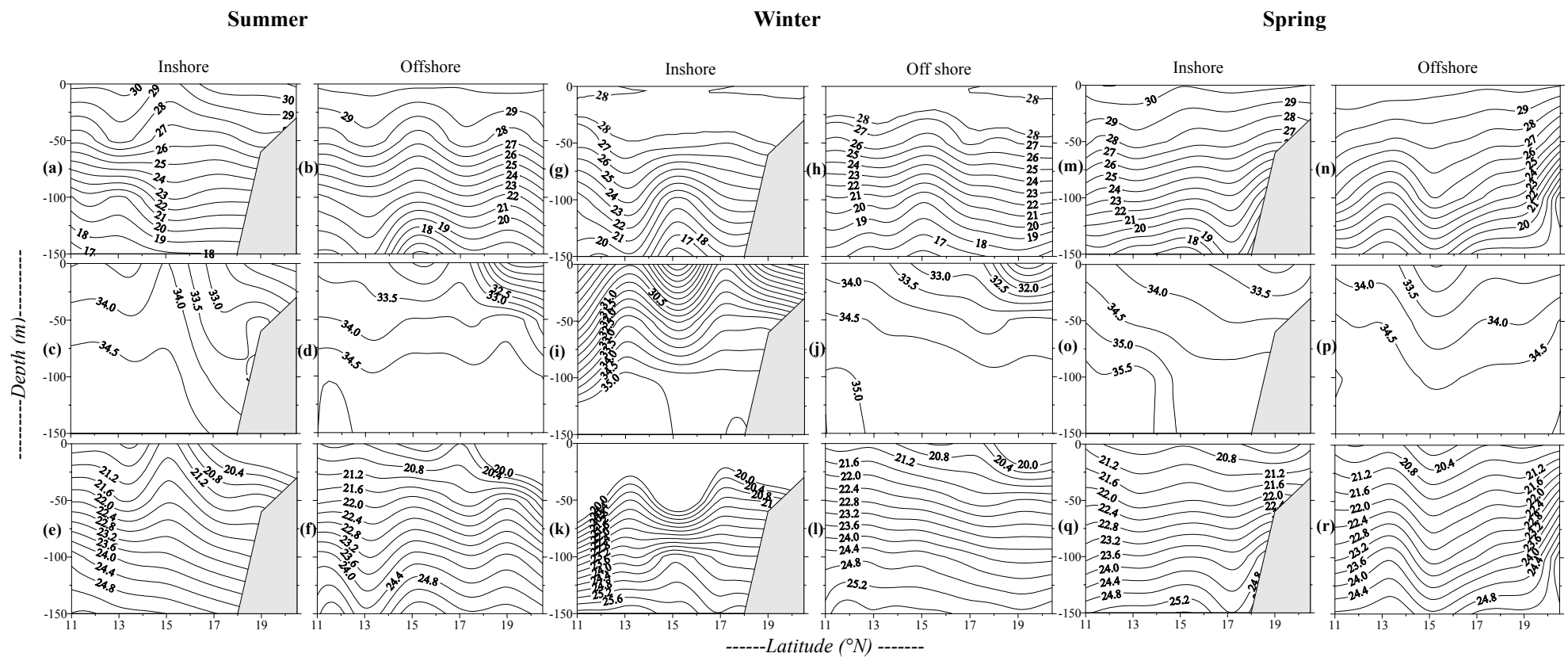

Figure. 4 - Vertical distribution of (a, b, g, h, m, \& n) Temperature $\left({ }^{\circ} \mathrm{C}\right),(\mathrm{c}, \mathrm{d}, \mathrm{i}, \mathrm{j}, \mathrm{o}$ \& p) Salinity, and (e, f, k, I, q \& r) Sigma -t upto $150 \mathrm{~m}$ water column of inshore and offshore waters of western Bay of Bengal during summer, winter and spring inter monsoon seasons. 

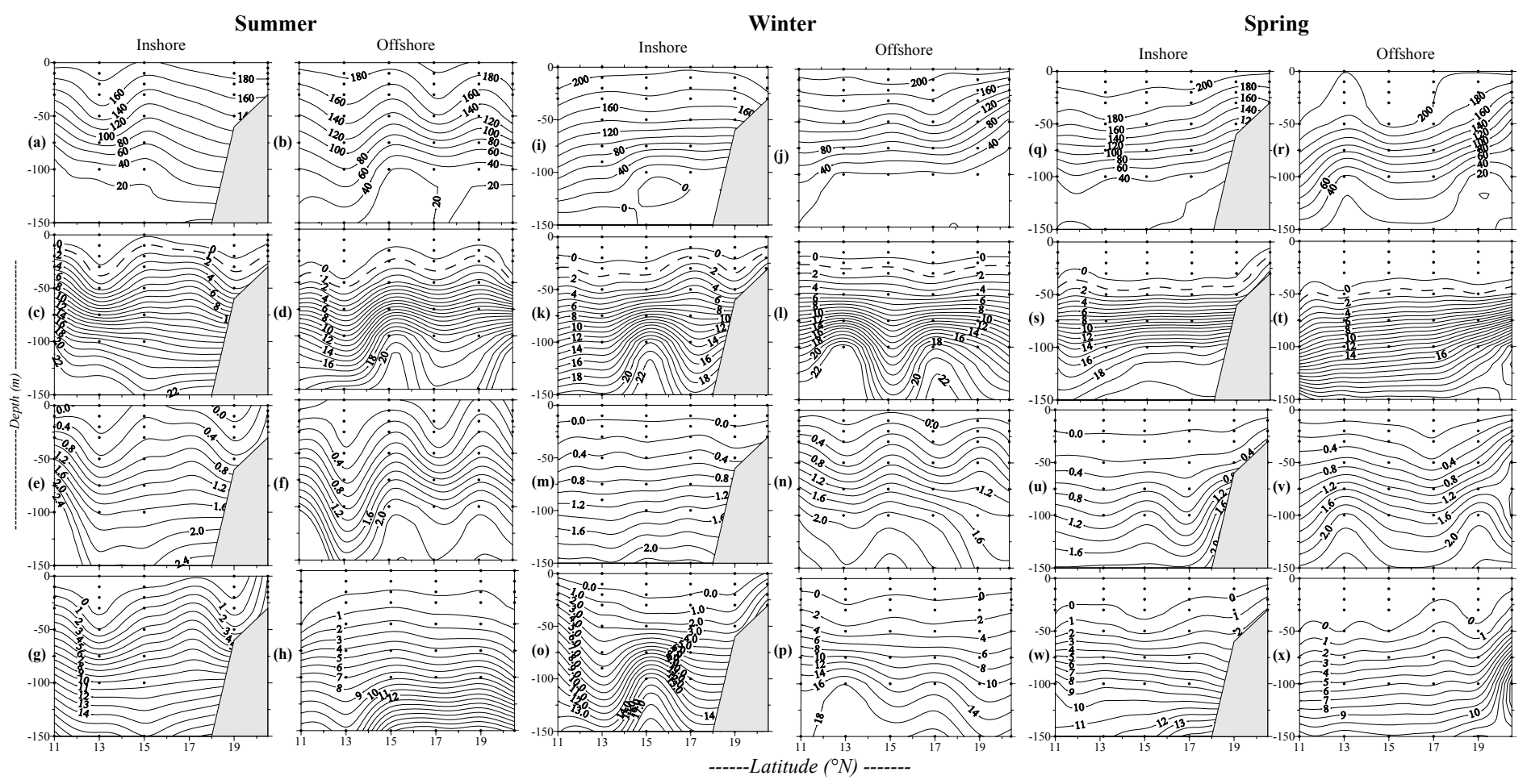

Figure. 5 - Vertical distribution of (a, b, i, j, q, \& r) Dissolved oxygen $(\mu \mathrm{M}),(\mathrm{c}, \mathrm{d}, \mathrm{k}, \mathrm{I}, \mathrm{s} \& \mathrm{t})$ Nitrate $(\mu \mathrm{M}),(\mathrm{e}, \mathrm{f}, \mathrm{m}, \mathrm{n}, \mathrm{u} \& \mathrm{v})$ Phosphate $(\mu \mathrm{M})$ \& $(\mathrm{g}, \mathrm{h}, \mathrm{o}, \mathrm{p}, \mathrm{w} \& \mathrm{x})$ Silicate $(\mu \mathrm{M}) 150 \mathrm{~m}$ water column of inshore and offshore waters of western Bay of Bengal during summer, winter and spring inter monsoon seasons. 
Surface
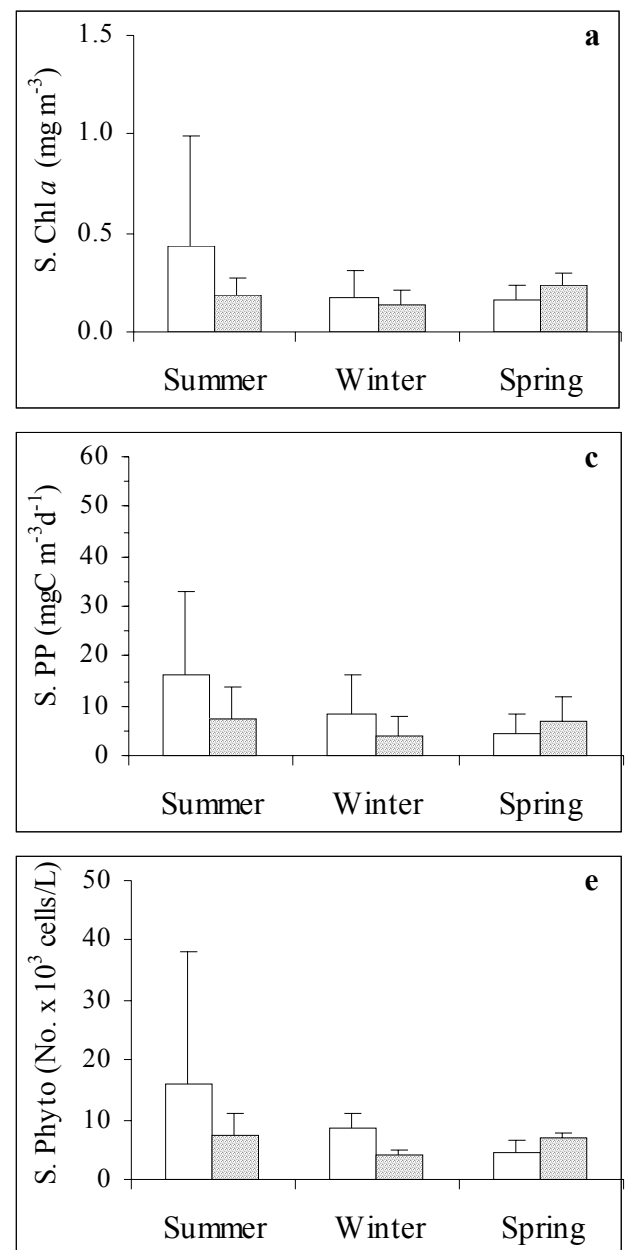

Column
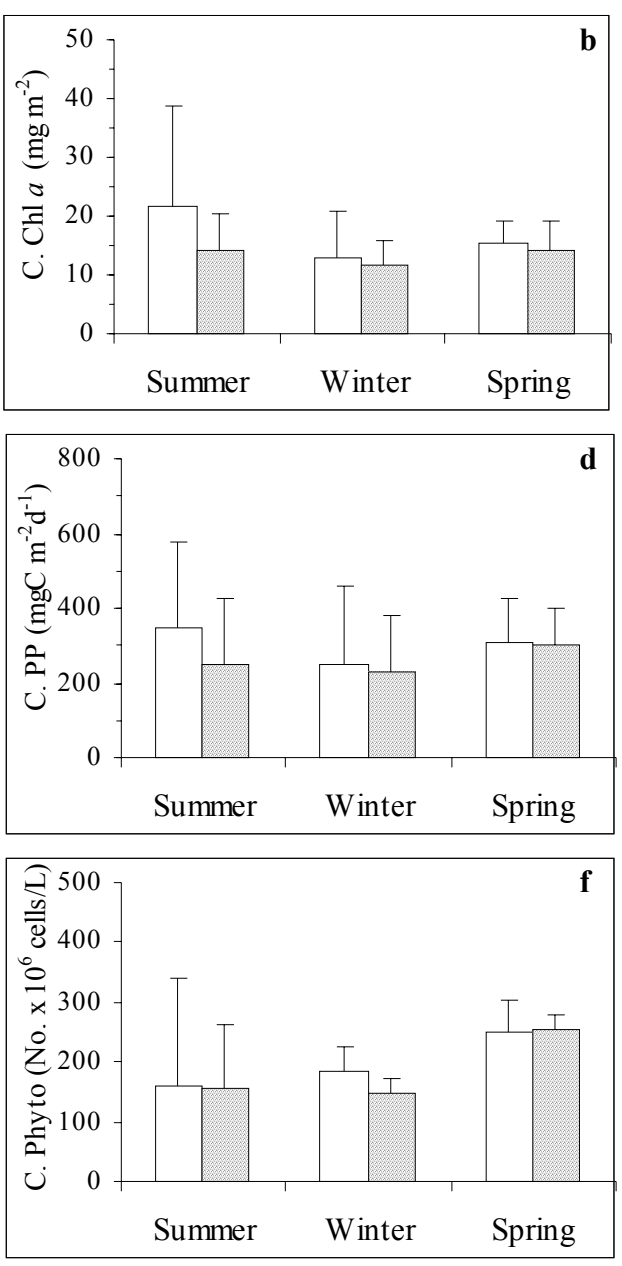

Inshore

Offshore

Figure . 6 - Distribution of average chlorophyll a, primary production and phytoplankton density (both surface and column) in the inshore/offshore waters of western Bay of Bengal during summer, winter and spring intermonsoon seasons 


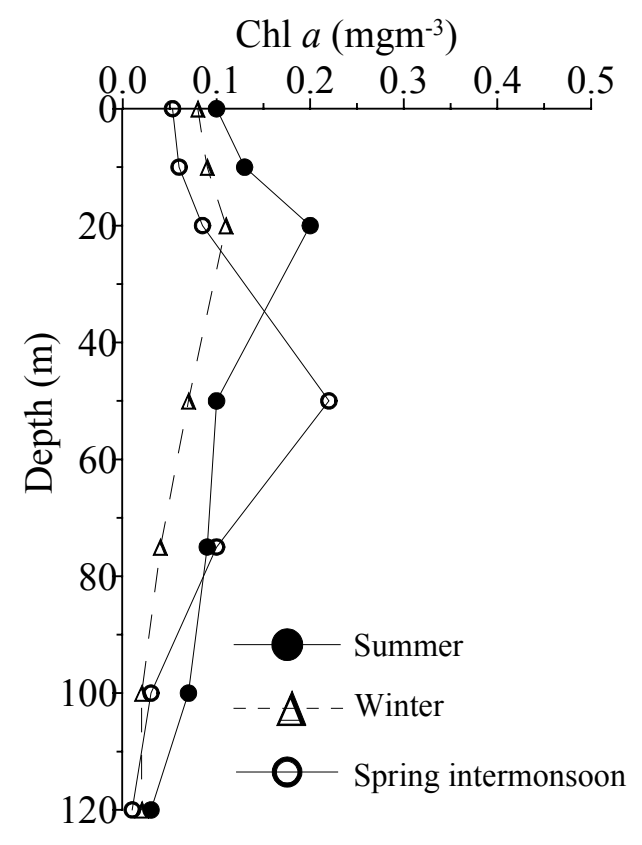

Figure. 7 - Seasonal trend in the vertical distribution of chlorophyll a $\left(\mathrm{mgm}^{-3}\right)$ in the western Bay of Bengal during summer, winter and spring intermonsoon seasons. 

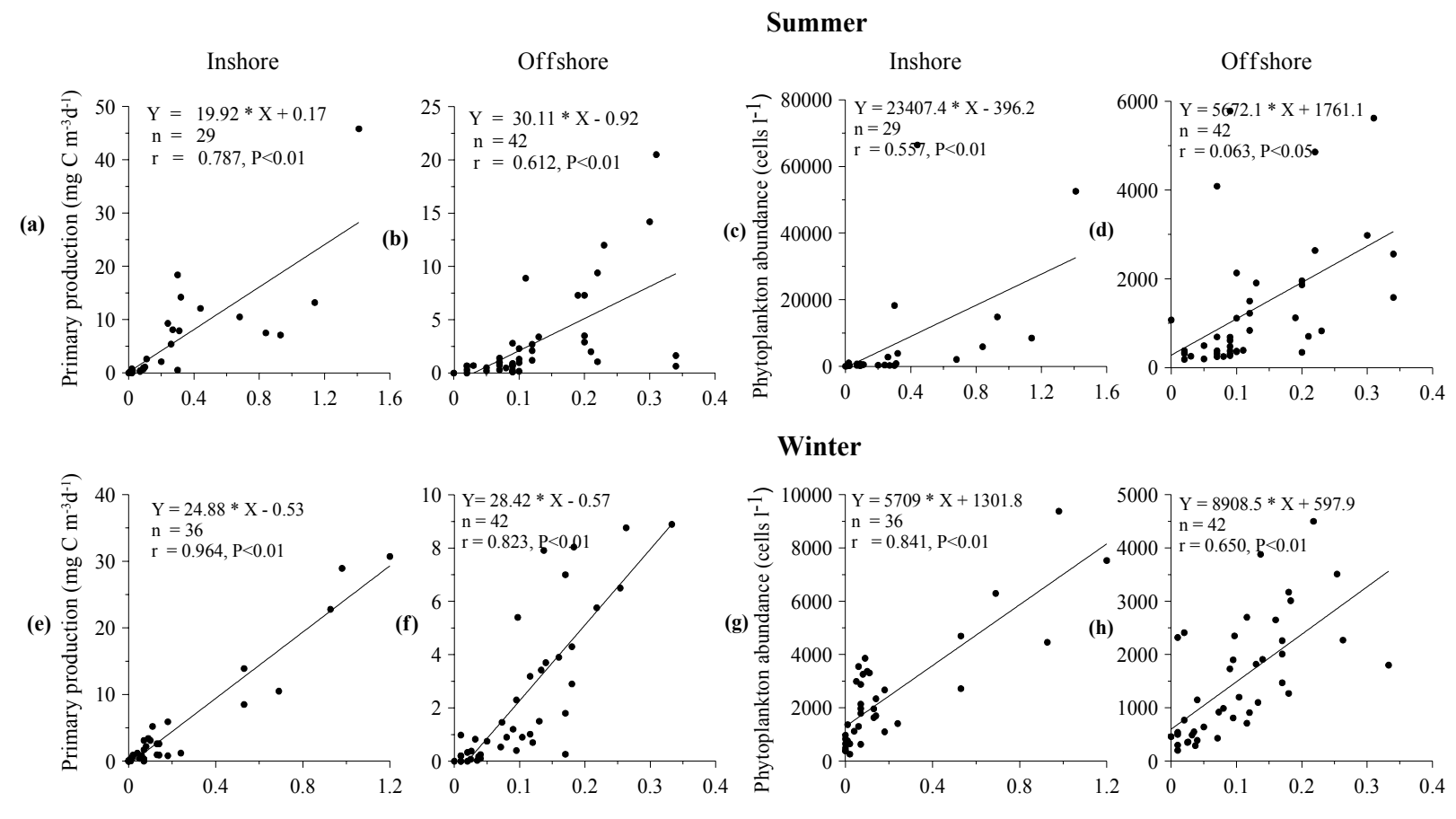

Winter
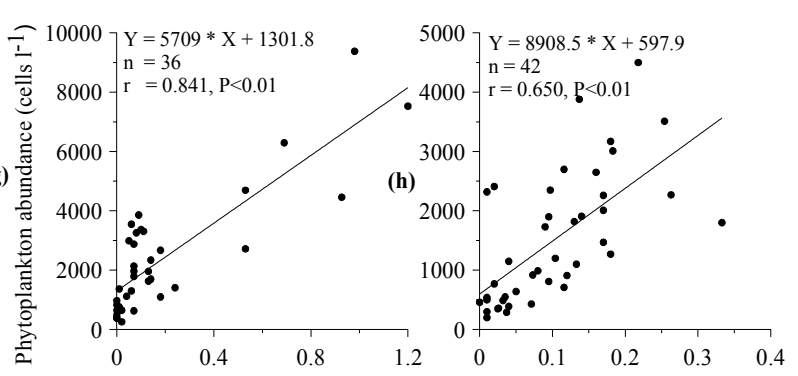

Spring
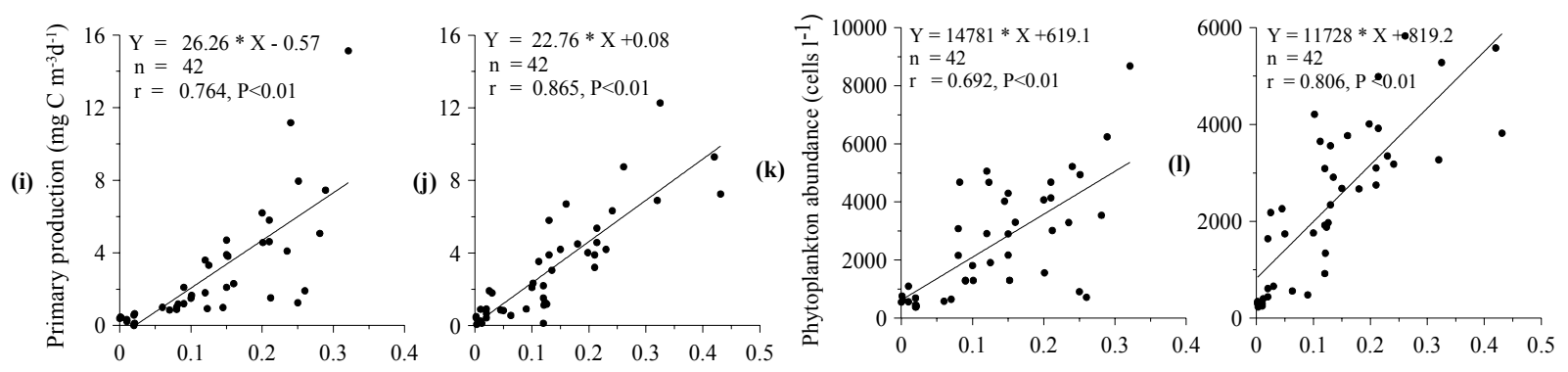

---Chlorophyll $a\left(\mathrm{mg} \mathrm{m}^{-3}\right)$

Figure. 8 - Linear correlation of chlorophyll a to primary production and phytoplankton density of inshore and offshore waters of the western Bay of Bengal during different seasons 


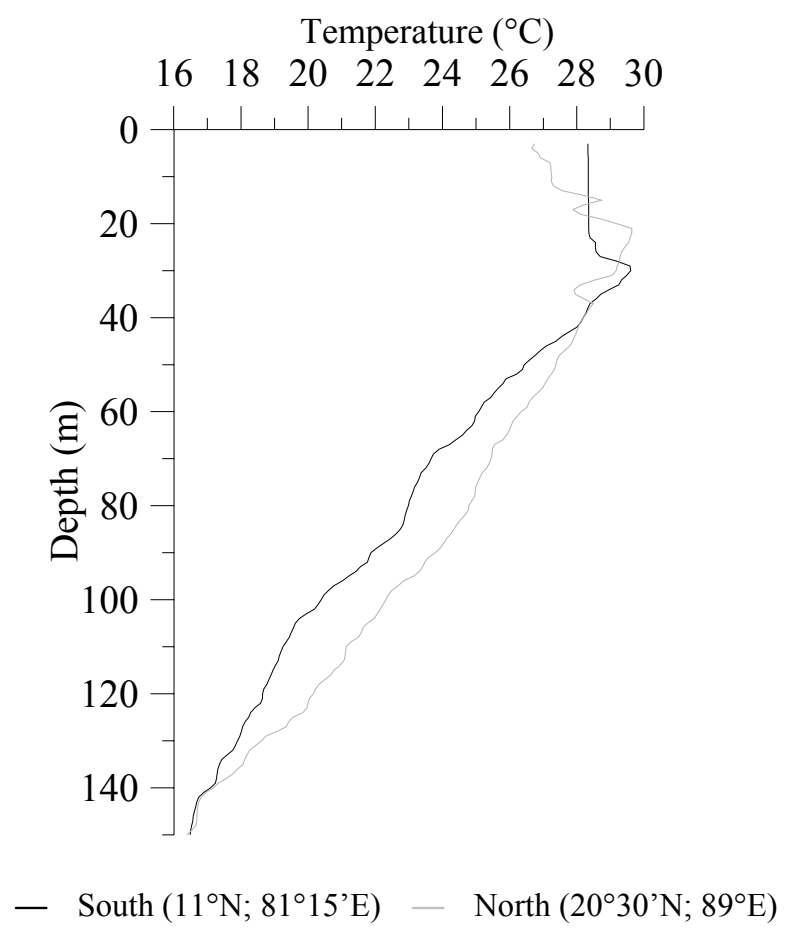

Figure. 7 - General trend in the vertical distribution of temperature $\left({ }^{\circ} \mathrm{C}\right)$ in the western Bay of Bengal during winter monsoon season. 
a)

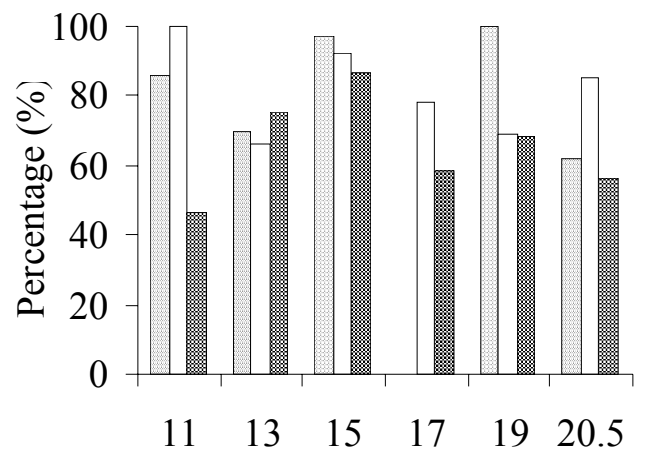

c)

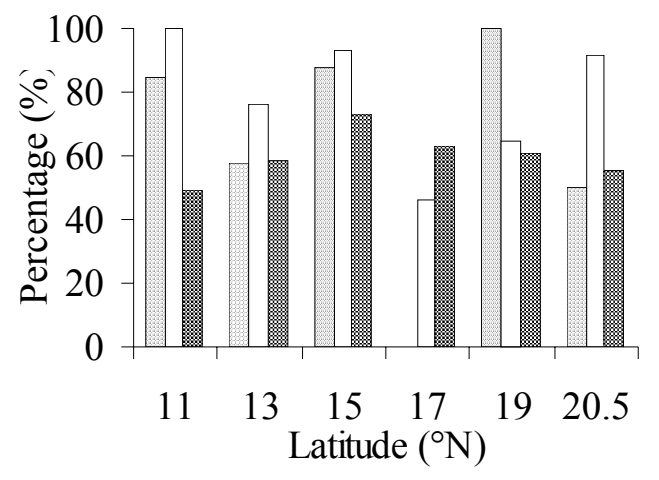

b)

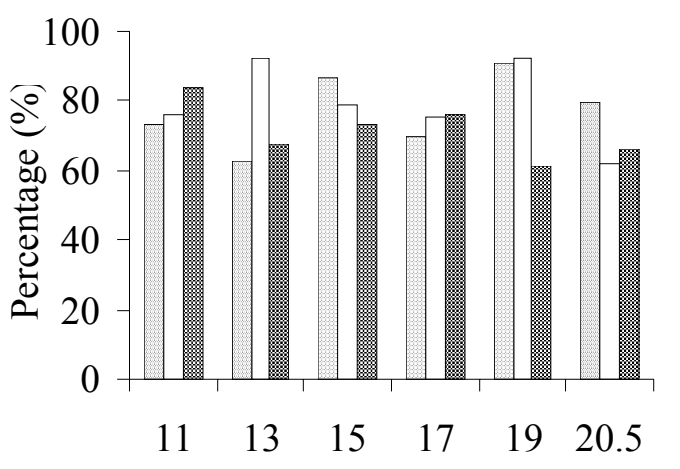

d)

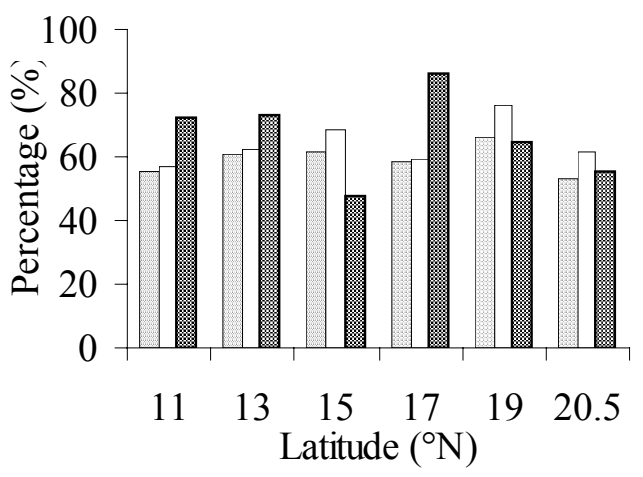

$$
\text { Summer } \square \text { winter } \square \text { spring intermonsoon }
$$

Figure. 10 - Percentage contribution of primary production $(a \& b)$ and chlorophyll a (c \& d) in top $50 \mathrm{~m}$ of the $0-120 \mathrm{~m}$ water column in inshore and offshore waters of western Bay of Bengal during summer, winter and spring intermonsoon. 